\title{
COMPARATIVE PROFITABILITY ANALYSIS OF BROILER FARMING UNDER AFTAB BAHUMUKHI FARM LIMITED SUPERVISION AND FARMERS' OWN MANAGEMENT
}

\author{
S. Akhter1, M. H. A. Rashid ${ }^{2}$ and H. Uddin ${ }^{3}$ \\ Department of Agricultural Economics, Bangladesh Agricultural University \\ Mymensingh-2202, Bangladesh
}

\begin{abstract}
This study was conducted to estimate the comparative profitability of Aftab Bahumukhi Farm Limited (ABFL) supervised broiler farms and farmers' own managed broiler farms. Data were collected from randomly selected 90 broiler farmers of which 45 were ABFL supervised farmers and 45 were own managed farmers. Descriptive statistical techniques were used to estimate cost and returns of broiler farming. The study revealed that on an average, total cost of raising broiler per batch per 1000 birds was estimated at Tk. 99,429.00 and Tk. 1,06,330.00 for ABFL supervised farms and farmers own managed farms respectively. The respective average variable costs and fixed costs per batch per 1000 birds were calculated at Tk. 96,218.00 and Tk. 1,02,926.00 respectively. These accounted for 96.77 percent and 96.80 percent of total costs respectably for ABFL supervised farms and independently managed farms. The estimated average gross return was Tk. 1,03,334.00 for ABFL supervised farms and Tk. 1,09,961.00 for independent farms respectively. The average gross margins per batch per farm for 1000 birds were at Tk. 7,470.00 and Tk. 7,035.00 for the ABFL supervised farms and for farmers own managed farms respectively and average net returns were estimated at Tk. 4,259.00 for ABFL supervised farms and Tk. 3,631.00 for farmers own managed farms respectively. From the statistical evidence it was found that profit earned by ABFL supervised broiler farms and own managed broiler farms were not significantly different.
\end{abstract}

Key words : Profitability, Comparative, Broiler farming, Supervised, Own management

\section{INTRODUCTION}

Livestock and poultry sub - sector has turned out to be promising dynamic sector with enormous potential for rapid poverty reduction. The sub- sector as a whole has shown growth rate of about 2.8 percent annually over the nineties (PRSP, 2004). During 2001 to 2004/05, agricultural output grew at 5.5\% while livestock output alone grew at 5.5\% against the crop output growth of $0.36 \%$ (Jabbar et. al, 2005). The poultry sub- sector is

1 Lecturer and 2Professor, Department of Agricultural Economics, Bangladesh Agricultural University Mymensingh-2202, Bangladesh

3 Officer, IBBL, Ashuganj Branch, Ashuganj, Brahmanbaria, Bangladesh 
crucially important in the context of agricultural growth and improvements of nutritional status of people in Bangladesh. The per capita consumption of animal protein in Bangladesh is only 11.8 gm per day (BBS, 2001) whereas the standard requirement of 36 gm is recommended by UNO (Begum, 2005). This sector can contribute in combating this problem where about 37 percent (Bhuiyan, 2003) of the total animal protein supplied in the country comes from poultry meat. In order to meet the protein requirement, it is essential to increase productivity of broiler production. However poultry farming, particularly broiler, serve as a ready source of income among the poor people when they need money and creates the employment opportunity for educated unemployed youth and also for women.

Contract broiler production means agreements between farmers and companies that specify conditions of producing and marketing of broilers. In most of the developed countries, contract farming system in broiler production was launched before 1960. In Bangladesh, it was started in 1994 through ABFL which is one of the leading poultry farms under the Islam Group Ltd, Dhaka. ABFL was established at Bhagalpur, Bajitpur in the district of Kishoreganj and many peoples are employed in this farm, from management personnel to the laborer. Thus, poultry rearing is no more considered as low prestigious occupation fit for only weaker sections of the society. It has now become a full time job for many people. Many new farms are being setup every year although it was seriously affected by the rumor of bird flue in recent past. Moreover poultry industry has been suffering from some serious weakness which needs to be addressed properly. It needs proper management, research, training and innovative planning to fully harness its potentiality. Thus the present study was undertaken to estimate comparative profitability of broiler farming under ABFL supervision and farmers' own management. The study also aimed to formulate some policy implications.

\section{MATERIALS AND METHODS}

Three Upazilas of Kishoreganj district namely: Bajitpur, Kuliarchar and Kishoreganj Sadar were selected purposively to achieve the objectives of the study. Data were collected from the sample broiler farmers of these areas during February to April, 2008 through direct interviews. After listing of 100 contract broiler farmers, prepared with the help of the officials of ABFL a sample of 45 broiler farms under ABFL supervision was randomly chosen and a sample of 45 own managed broiler farms was purposively chosen from the study area. All the collected data were then edited and it was converted into standard international units from local units. Both tabular and statistical analyses were used in the present study. Descriptive statistical techniques, such as the sum, average, percentage, standard deviation were used for aalyzing the collected data to show the comparative performance of ABFL supervised broiler farms and independently managed broiler farms.

The following profit $(\pi)$ equation was used to assess the profitability of broiler farms.

$\pi=\mathrm{Pm} \cdot \mathrm{Qm}+\mathrm{P}_{1} \mathrm{Q}_{1}-\Sigma\left(\mathrm{Px}_{\mathrm{i}} \cdot \mathrm{X}_{\mathrm{i}}\right)-\mathrm{TFC}$. 
Where,

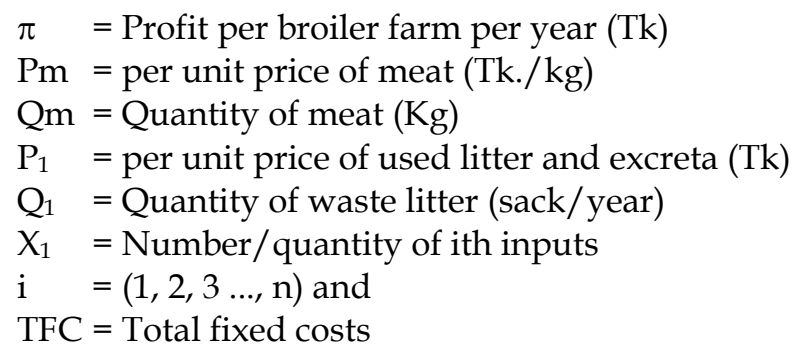

In this study, costs and returns analyses were done on both variable and total cost basis. Gross margin was calculated using the following formula :

Gross margin $(\mathrm{GM})=$ Gross return $(\mathrm{GR})-$ Variable cost $(\mathrm{VC})$

\section{RESULTS AND DISCUSSION}

\section{Cost of broiler production}

Production costs means the expenses incurred in producing output. Farmers' decisions are greatly influenced by this cost. In this study, the total costs per batch per 1000 birds were worked out (ignoring farm sizes). Here variable and fixed costs were calculated separately. Table 1 presents the total costs of broiler farms under ABFL supervision and farmers' own managed broiler farms. On an average, total cost of raising broiler per batch per 1000 birds was estimated at Tk. 99,429.00 and Tk. 1,06,330.00 for ABFL supervised farms and farmers' own managed farms respectively. The respective average variable costs and fixed costs per batch per 1000 birds were calculated at Tk.96, 218.00 and Tk. 1,02,926.00 respectively. These accounted for 96.77 percent and 96.80 percent of total costs respectably for ABFL supervised farms and independently managed farms. The major cost items of broiler production included were feed cost, day old chick cost, labor cost, veterinary service and medicine cost, electricity cost, litter cost, transportation cost, housing cost and interest on operating capital. Feed cost was the largest cost items of raising broilers. It is evident from Table 1 that average feed costs per batch per 1000 birds were estimated at Tk. 63,641.00 and Tk. 64,126.00 for ABFL supervised farms and independently managed farms. Feed cost was covered 64.00 percent of the total cost for ABFL and 60.31 for independent farms. Hence one of the main opportunities for increasing profit is to low feed costs. Average cost of day old chick per batch per 1000 bird was Tk. 22,977.00 and Tk. 26,288.00 for ABFL supervised farms and independently managed farms. This cost shares 23.11 percent and 24.72 percent of total costs of respective farms which is the second largest cost item of producing broiler. Labor cost shared 2.35 percent and 2.46 percent of total costs respectively for ABFL supervised farms and farmers own managed farms and veterinary cost covered 3.85 percent and 5.49 percent of the total costs for the respective farms (Table 1). Fixed cost included housing cost, tools and equipment cost and interest on operating capital which shares only 3.23 
and 3.20 per batch per 1000 birds for ABFL supervised farms and farmers own managed farms respectively.

Table 1. Total costs of broiler production per batch per farm for 1000 birds under ABFL supervision and farmer's own management

\begin{tabular}{|c|c|c|c|c|c|c|c|c|c|}
\hline \multirow[t]{2}{*}{ Particulars } & \multirow[t]{2}{*}{ Unit } & \multicolumn{4}{|c|}{ ABFL } & \multicolumn{4}{|c|}{ Farmer's own } \\
\hline & & $\begin{array}{c}\text { Price } \\
(\mathrm{Tk})\end{array}$ & $\begin{array}{l}\text { Average } \\
\text { quantity }\end{array}$ & Cost & $\begin{array}{c}\text { Percent } \\
\text { of total } \\
\text { cost }\end{array}$ & $\begin{array}{c}\text { Price } \\
\text { (Tk) }\end{array}$ & $\begin{array}{l}\text { Average } \\
\text { quantity }\end{array}$ & Cost & $\begin{array}{c}\text { Percent } \\
\text { of total } \\
\text { cost }\end{array}$ \\
\hline A. Variable cost & Tk & - & - & $\begin{array}{c}96,218.00 \\
(5924)\end{array}$ & 96.77 & - & - & $\begin{array}{c}1,02,926.00 \\
(8657)\end{array}$ & 96.80 \\
\hline i. Feed cost & $\mathrm{Kg}$ & $\begin{array}{l}23.00 \\
(0.00)\end{array}$ & $\begin{array}{c}2,767.0 \\
(260)\end{array}$ & $\begin{array}{l}63,641.00 \\
(5983)\end{array}$ & 64.00 & $\begin{array}{l}24.56 \\
(0.69)\end{array}$ & $\begin{array}{c}2,611.00 \\
(294)\end{array}$ & $\begin{array}{l}64,126.00 \\
(8142)\end{array}$ & 60.31 \\
\hline ii. Day old chick cost & No & $\begin{array}{l}22.97 \\
(2.21)\end{array}$ & - & $\begin{array}{l}22,977.00 \\
(2210)\end{array}$ & 23.11 & $\begin{array}{l}26.36 \\
(2.17)\end{array}$ & - & $\begin{array}{l}26,288.00 \\
(2170)\end{array}$ & 24.72 \\
\hline iii. Labor cost & $\begin{array}{l}\text { Person } \\
\text { day }\end{array}$ & $\begin{array}{l}88.00 \\
(18.9)\end{array}$ & $\begin{array}{l}27.00 \\
(17.50)\end{array}$ & $\begin{array}{l}2,336.00 \\
(661.66)\end{array}$ & 2.35 & $\begin{array}{l}91.00 \\
(23.6)\end{array}$ & $\begin{array}{l}29.00 \\
(16.78)\end{array}$ & $\begin{array}{c}2,618.00 \\
(829.3)\end{array}$ & 2.46 \\
\hline $\begin{array}{l}\text { iv. Veterinary } \\
\text { service and } \\
\text { medicine cost }\end{array}$ & Tk & - & - & $\begin{array}{c}3,828.00 \\
(1049)\end{array}$ & 3.85 & - & - & $\begin{array}{c}5,841.00 \\
(1529)\end{array}$ & 5.49 \\
\hline v. Electricity cost & Tk & - & - & $\begin{array}{c}576.00 \\
(127)\end{array}$ & 0.58 & - & - & $\begin{array}{c}613.00 \\
(144)\end{array}$ & 0.58 \\
\hline vi. Litter cost & Tk & - & - & $\begin{array}{c}1,081.00 \\
(147)\end{array}$ & 1.09 & - & - & $\begin{array}{c}989.00 \\
(116)\end{array}$ & 0.93 \\
\hline $\begin{array}{l}\text { vii. Transportation } \\
\text { cost }\end{array}$ & Tk & - & - & $\begin{array}{c}1,020.00 \\
(212)\end{array}$ & 1.03 & - & - & $\begin{array}{c}1,545.00 \\
(356)\end{array}$ & 1.45 \\
\hline $\begin{array}{l}\text { viii. Repairing cost } \\
\text { of house }\end{array}$ & $\mathrm{Tk}$ & - & - & $\begin{array}{c}244.00 \\
(102)\end{array}$ & 0.25 & - & - & $\begin{array}{l}267.00 \\
(88.7)\end{array}$ & 0.25 \\
\hline $\begin{array}{l}\text { ix. Repairing cost of } \\
\text { tools and } \\
\text { equipment }\end{array}$ & Tk & - & - & $\begin{array}{c}69.00 \\
(45.02)\end{array}$ & 0.07 & - & - & $\begin{array}{l}116.00 \\
(27.96)\end{array}$ & 0.11 \\
\hline$x$. Others cost & Tk & - & - & $\begin{array}{c}446.00 \\
(151)\end{array}$ & 0.45 & - & - & $\begin{array}{c}523.00 \\
(157)\end{array}$ & 0.49 \\
\hline B. Fixed cost & Tk & - & - & $\begin{array}{c}3,211.00 \\
(247)\end{array}$ & 3.23 & - & - & $\begin{array}{l}3,404.00 \\
(295)\end{array}$ & 3.20 \\
\hline i. . Housing cost & Tk & - & - & $\begin{array}{c}430.00 \\
(130)\end{array}$ & 0.43 & - & - & $\begin{array}{c}401.00 \\
(124)\end{array}$ & 0.38 \\
\hline $\begin{array}{l}\text { ii. Tools and } \\
\text { equipment cost- }\end{array}$ & Tk & - & - & $\begin{array}{l}376.00 \\
(87.36)\end{array}$ & 0.38 & - & - & $\begin{array}{l}428.00 \\
(91.46)\end{array}$ & 0.40 \\
\hline $\begin{array}{l}\text { iii Interest on } \\
\text { operating capital }\end{array}$ & Tk & - & - & $\begin{array}{c}2,405.00 \\
(148)\end{array}$ & 2.42 & - & - & $\begin{array}{c}2,575.00 \\
(212)\end{array}$ & 2.42 \\
\hline Total cost $(A+B)$ & Tk & - & - & $\begin{array}{c}99,429.00 \\
(6087)\end{array}$ & 100.00 & - & - & $\begin{array}{c}1,06,330.00 \\
(8901)\end{array}$ & 100.00 \\
\hline
\end{tabular}

Source : Field Survey, 2008; Figures within parentheses indicate standard deviation 


\section{Return from broiler production}

Gross return was estimated by adding the values of live weight broiler, used litters and bird excreta. It was noted that average price of live weight broiler received by the ABFL supervised farms was Tk. 73.60 per $\mathrm{kg}$ and Tk. 80.51 per $\mathrm{kg}$ by independent farm. It is evident from Table 2 that the average gross return was Tk. 1,03,334.00 for ABFL supervised farms and Tk. 1,09,961.00 for independent farms respectively. Gross margin was calculated by deducting variable costs from gross return on account of the enterprise. Table 3 shows average gross margins per batch per farm for 1000 birds were at Tk. 7,470.00 and Tk. 7,035.00 for the ABFL supervised farms and for farmers own managed farms respectively. Table 3 shows that average net returns were estimated at Tk 4,259.00 for ABFL supervised farms and Tk. 3,631.00 for farmers own managed farms respectively.

Table 2. Gross return from broiler production per batch per farm for 1000 birds for ABFL supervised and farmer's own managed farms

\begin{tabular}{l|c|c|c|c|c|c|c}
\hline Particulars & \multirow{2}{*}{ Unit } & \multicolumn{3}{|c|}{ ABFL } & \multicolumn{3}{c}{ Farmer's own } \\
\cline { 3 - 8 } & & Price/unit & Quantity & $\begin{array}{c}\text { Value } \\
(\mathrm{Tk})\end{array}$ & Price/unit & Quantity & $\begin{array}{c}\text { Value } \\
(\mathrm{Tk})\end{array}$ \\
\hline Broiler & $\mathrm{Kg}$ & 73.6 & $1,404.0$ & $1,03,334.00$ & 80.51 & $1,361.00$ & $1,09,574.00$ \\
& & $(3.99)$ & $(168)$ & $(11420)$ & $(3.18)$ & $(144)$ & $(11049)$ \\
Used litter & Tk & - & - & 354.00 & - & - & 387.00 \\
& & & & $(94)$ & & - & $1,09,961.00$ \\
& Tk & - & - & $1,03,688.00$ & - & $(11062)$ \\
\hline
\end{tabular}

Source : Akhter, 2008; Figures within parentheses indicate standard deviation

Table 3. Gross margin and net return from broiler farms

\begin{tabular}{l|c|c|c|c}
\hline \multirow{2}{*}{ Particulars } & \multicolumn{2}{c|}{ ABFL } & \multicolumn{2}{c}{ Farmer's own } \\
\cline { 2 - 5 } & Unit & Value (Tk) & Unit & Value (Tk) \\
\hline Gross return & Tk & $1,03,688.00$ & Tk & $1,09,961.00$ \\
Variable cost & Tk & $96,218.00$ & Tk & $1,02,926.00$ \\
Total cost & Tk & $99,429.00$ & Tk & $1,06,330.00$ \\
Gross margin & Tk & $7,470.00$ & Tk & $7,035.00$ \\
Net return & Tk & $4,259.00( \pm 1429)$ & Tk & $3,631.00( \pm 819)$ \\
\hline
\end{tabular}

Source : Akhter, 2008; Figures within parentheses indicate standard error

\section{CONCLUSION}

Farmers of ABFL supervised and own managed farms are making profit from broiler farming in the study areas. From the statistical evidence (standard error basis) it was found that profit earned by ABFL supervised broiler farmers and own managed broiler farmers were not significantly different. It was also found from the farm survey that numbers of ABFL contract farmers were reduced (Akhter, 2008). Thus the contracts needs 
to be reviewed and updated with respect to changing market conditions in a participatory manner involving both the parties for retaining the confidence of the contract growers.

\section{REFERNECES}

Akhter, S. 2008. Broiler Farming under Aftab Bahumukhi Farm Limited Supervision and Farmers' Own Management : A Comparative Efficiency Analysis. Unpublished M. S. Thesis, Department of Agricultural Economics, Bangladesh Agricultural University, Mymensingh.

Bangladesh Population Census, 2001. Bangladesh Bureau of Statistics, Statistics Division, Ministry of Planning, Government of the Peoples Republic of Bangladesh, Dhaka, Bangladesh.

Begum, I.A. 2005. 'Vertically Integrated Contract and Independent Poultry Farming System in Bangladesh a Profitability Analysis'. Bangladesh Livestock Research for Rural Development. 17(8): 2005.

Bhuiyan, H. A. 2003. A Comparative Economic Analysis of Poultry Production under Supervision of Aftab Bahumukhi Farm and Farmers own Management in Some Selected Areas of Kishoreganj District. Unpublished M. S. Thesis, Department of Agricultural Economics, Bangladesh Agricultural University, Mymensingh.

Jabbar, M. A., Islam, S. M. F., Delgado, C., Ehuis, Akanda, M. A., Khan, I. and Kamruzzaman, M. 2005. 'Policy and Scale Factors Influencing Efficiency in Dairy and Poultry Production in Bangladesh'. International Livestock Research Institute, Nairobi, Kenya. 4-5.

PRSP, 2004. Unlocking the Potential, National Strategy for Accelerated Poverty Reduction, General Economics Division, Planning Commission, Government of the People's Republic of Bangladesh. 